\title{
Pengembangan Butir Soal Literasi Kimia pada Materi Ikatan Kimia Menggunakan Model Rasch
}

\section{Development of Chemical Literacy Items in Chemical Bonding Materials Using the Rasch Model}

\author{
M Rizki $^{1}$ and E Yusmaita ${ }^{1 *}$ \\ 1 Pendidikan Kimia, Universitas Negeri Padang, \\ Jl. Prof. Dr. Hamka, Air Tawar Barat, Padang Utara, Sumatera Barat, Indonesia 25171 \\ *ekayusmaita@fmipa.unp.ac.id
}

\section{ARTICLE INFO}

Received on:

14 August 2021

Revised till:

30 August 2021

Accepted on:

31 August 2021

Publisher version published on:

08 September 2021

\begin{abstract}
This study aims to develop chemical literacy items on chemical bonding material that can be used to measure students' literacy skills, help students understand chemical literacy-based questions, understand chemistry, communicate chemistry orally and in writing, and apply their ability to solve problems in daily life. The type of research is development research with Model of Educational Reconstruction (MER) design. The content validity test was carried out by five validators and analysed using the Rasch model with the facets application. Meanwhile, empirical testing of students was analysed using the Rasch model with the winsteps application. The results of the content validity analysis in this study showed the results of the agreement (exact agreements) of $86,8 \%$ and the estimated results of the approval (expected agreements) of $87,8 \%$, and the results of the analysis of chemical literacy instruments had a valid category and had a reliability value of 0,96.
\end{abstract}

\section{KEYWORDS}

Chemical Literacy Instrument, MER, Rasch Model

\section{ABSTRAK}

Penelitian ini bertujuan untuk mengembangkan butir soal literasi kimia pada materi ikatan kimia yang dapat digunakan untuk mengukur kemampuan literasi peserta didik, membantu peserta didik dalam memahami soal berbasis literasi kimia, memahami ilmu kimia, mengomunikasikan ilmu kimia secara lisan dan tulisan serta menerapkan kemampuannya dalam memecahkan masalah dalam kehidupan sehari-hari. Jenis penelitian adalah penelitian pengembangan dengan desain Model of Educational Reconstruction (MER). Pengujian validitas konten dilakukan oleh lima validator dan dianalisis menggunakan model Rasch dengan aplikasi facets. Sedangkan pengujian secara empiris terhadap peserta didik dianalisis menggunakan model Rasch dengan aplikasi winsteps. Hasil analisis validitas konten pada penelitian ini menunjukkan hasil persetujuan (exact agreements) sebesar $86,8 \%$ dan perkiraan hasil persetujuan (expected agreements) sebesar 87,8\%. Hasil analisis instrumen literasi kimia memiliki kategori valid dan memiliki nilai reliabilitas 0,96 .

KATA KUNCI

Instrumen Literasi Kimia, MER, Model Rasch 


\section{PENDAHULUAN}

Kementerian Pendidikan dan Kebudayaan Indonesia (Kemendikbud) berupaya meningkatkan kualitas pendidikan dengan cara mengeluarkan Asesmen Nasional. Salah satu kebijakan Asesmen nasional ialah Asesmen Kompetensi Minimum (AKM) yang digunakan untuk mengevaluasi hasil belajar dengan berfokus mengukur kemampuan literasi dan numerasi peserta didik ${ }^{[1]}$. Menurut Kemendikbud literasi merupakan kemampuan dalam menganalisis dan memahami suatu bacaan, yang mana tidak hanya sekadar membaca tetapi juga dapat mengetahui makna dibalik suatu bacaan ${ }^{[2]}$. Kemampuan literasi diharapkan dapat mendorong peserta didik dalam memahami pengetahuan ilmiah untuk menghadapi permasalahan di kehidupan sehari-hari secara rasional, kreatif, dan dapat mengambil keputusan berdasarkan pendekatan ilmiah $^{[3]}$.

Salah satu program yang melakukan penilaian literasi sains peserta didik secara Internasional adalah PISA (Programme for International Student Assessment) yang diselenggarakan oleh OECD (Organization for Economic Co-operation and Development ${ }^{[4]}$. Berdasarkan penilaian PISA, kualitas pendidikan Indonesia khususnya pendidikan sains masih tergolong rendah. Hal ini ditunjukkan dari peringkat Indonesia pada tahun 2018 menempati posisi ke-62 dari 71 negara ${ }^{[5]}$.

Literasi kimia merupakan kemampuan individu dalam menjelaskan fenomena ilmiah menggunakan konsep kimia, memecahkan masalah dengan menggunakan pemahaman kimia dan memahami serta menerapkan aplikasi kimia dalam kehidupan sehari-hari ${ }^{[6]}$. Materi ikatan kimia mencakup banyak teori dan bersifat abstrak yang harus dipahami oleh peserta didik dengan baik. Materi ini akan sulit dipahami apabila guru tidak menggambarkan sisi mikroskopis serta memberikan contoh yang berkaitan dengan kehidupan pada saat pembelajaran ${ }^{[7]}$.

Penelitian tentang pengembangan dan analisis instrumen literasi kimia di Indonesia sudah mulai banyak dilakukan, seperti penelitian yang dilakukan oleh Arabbani tentang analysis the quality of instrument for measuring chemical literacy abilities of high school student using rasch model ${ }^{[8]}$; dan penelitian yang dilakukan oleh Sadhu dan Laksono tentang development and validation of an integrated assessment for measuring critical thinking and chemical literacy in chemical equilibrium ${ }^{[9]}$; dan penelitian yang dilakukan oleh Fahmina tentang content validity uses rasch model on computerized testlet instrument to measure chemical literacy capabilities ${ }^{[10]}$; penelitian yang dilakukan oleh Eka Yusmaita tentang chemical literacy test instrument designing on buffer topic using model of educational reconstruction (MER)

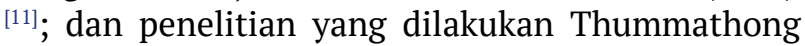
tentang construction of a chemical literacy test for engineering students ${ }^{[12]}$. Berdasarkan beberapa penelitian tersebut, diketahui bahwa beberapa aspek yang ingin diakses kepada peserta didik tidak serta merta bisa dilakukan dalam satu instrumen, aspek sikap misalnya, diakses melalui lembar wawancara atau observasi. Sehingganya diperlukan pengembangan instrumen tes literasi kimia yang mengkolaborasikan dua kerangka berpikir, yaitunya aspek-aspek literasi kimia yang dikembangkan oleh Shwartz dan level literasi Sains yang dikembangkan oleh Bybee ${ }^{[13]}$. Dengan terciptanya instrumen tes literasi kimia, diharapkan dapat menggambarkan profil kesulitan peserta didik dalam menjawab soal pokok uji literasi kimia dan dapat mengukur sejauh mana pemahaman peserta didik terhadap konsep kimia, permasalahan kimia, dan penerapannya dalam kehidupan ${ }^{[14]}$.

Pengembangan instrumen penilaian literasi kimia penting untuk dapat menilai literasi peserta didik karena penilaian tidak hanya berfokus aspek konten saja, namun juga dapat menilai aspek konteks dan penerapan ilmu kimia dalam menyelesaikan permasalahan sehari-hari ${ }^{[15]}$. Penilaian literasi kimia penting untuk dapat melihat tolak ukur kualitas pendidikan di Indonesia untuk dapat bersaing dengan negara-negara lain ${ }^{[16]}$.

Pencapaian literasi kimia bersifat kontinu dan terus berkembang dalam kehidupan manusia. Sehingga penilaian literasi kimia tidak berfokus untuk melihat apakah seseorang memiliki literasi atau tidak ${ }^{[14]}$. Pengembangan literasi kimia bertujuan untuk menimbulkan benih-benih literasi kimia pada peserta didik ${ }^{[17]}$. Untuk mengukur kemampuan literasi kimia peserta didik dibutuhkan instrumen tes yang baik. Instrumen tes yang baik adalah instrumen yang memiliki validitas yang baik pula ${ }^{[18]}$.

Analisis instrumen diperlukan untuk melihat kualitas instrumen. Ada dua pendekatan yang dikenal dalam menganalisis kualitas instrumen yaitu item response theory (IRT) dan classic test theory (CTT). IRT adalah teori penilaian modern yang menggabungkan respons dari responden terhadap item. Salah satu keunggulan IRT dibandingkan CTT adalah penggunaan peluang untuk jawaban peserta didik sebagai pengukuran. Pengukuran IRT menjelaskan interaksi antara subjek dan item tes, sehingga pengukuran memberikan hasil yang lebih objektif dan tepat. Salah satu model analisis yang menggunakan IRT adalah model rasch yang diperkenalkan oleh Georg Rasch pada $1960-\mathrm{an}^{[19]}$. Keunggulan model rasch adalah dapat mengidentifikasi respons error, mengidentifikasi tebakan, abilitas tidak hanya bergantung pada jawaban benar, dan dapat mengidentifikasi skor data hilang. Dalam menganalisis butir soal dengan model rasch dapat menggunakan program minifac ${ }^{[20]}$.

Instrumen Literasi kimia pada penelitian ini berdasarkan pada aspek literasi kimia yaitu aspek konten, aspek konteks, High Order Learning Skills (HOLS), dan sikap. Adapun rubrik penilaian berdasarkan pada level literasi kimia yaitu scientific illiteracy, nominal scientific literacy, functional scientific literacy, conceptual scientific literacy, dan multi-dimensional scientific literacy ${ }^{[17]}$. 


\section{METODE}

Jenis penelitian ini adalah pengembangan dengan menggunakan Model of Educational Reconstruction (MER). Ide dasar model penelitian ini adalah merekonstruksi struktur konten sesuai dengan tujuan pembelajaran kognitif dan afektif peserta didik terlebih dahulu sebelum digunakan dalam proses pengajaran ${ }^{[21]}$.

MER terdiri dari tiga komponen dasar, diantaranya: (1) analisis struktur konten, (2) penelitian mengajar dan belajar, dan (3) pengembangan dan evaluasi pembelajaran. Ketiga komponen MER saling terhubung satu sama lain membentuk alur yang sistematik ${ }^{[21]}$. Informasi ini dapat dilihat pada Gambar 1.

Pelaksanaan tahapan pada penelitian MER tidak mutlak harus menyelesaikan tahapan pertama terlebih dahulu, melainkan setiap tahapan dapat dilakukan secara bolak-balik sehingga ketiga

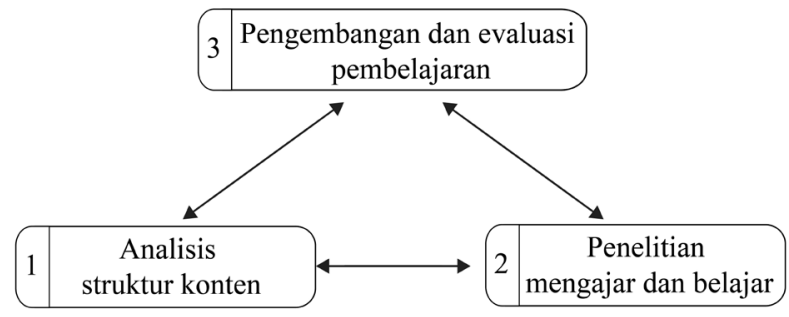

Gambar 1. Tiga komponen MER. komponennya saling memengaruhi dan sesuai berdasarkan kepentingan penelitian yang ingin dicapai ${ }^{[14]}$.

Pelaksanaan penelitian ini melakukan 3 tahapan dasar MER, tahapan tersebut adalah analisis struktur konten, penelitian belajar mengajar, dan pengembangan dan evaluasi. Tahap analisis struktur konten mencakup pada analisis silabus, analisis konten, dan analisis konteks serta analisis konten oleh Subject Matter Expert (SME). Kemudian tahap penelitian belajar dan mengajar dilakukan investigasi wawancara peserta didik dan tes skala kecil terhadap peserta didik. Terakhir tahap pengembangan dan evaluasi dilakukan pembentukan outline dasar instrumen. Dalam pelaksanaan penelitian ini ketiga tahapan model MER dimodifikasi menjadi skema baru, informasi ini dapat dilihat pada Gambar 2.

Uji validitas konten dilakukan oleh dua orang dosen kimia FMIPA UNP dan tiga orang guru kimia SMA. Instrumen penelitian yang digunakan adalah lembar validasi konten soal literasi kimia. Penilaian dilakukan dengan memberikan angka (1) jika tidak valid, (2) dapat dipertimbangkan, dan (3) jika valid. Data hasil validasi diolah menggunakan model rasch dengan aplikasi facets.

Penyelidikan secara empiris terhadap instrumen tes dilakukan pada 59 orang peserta didik yang sudah mempelajari materi ikatan kimia. Hasil

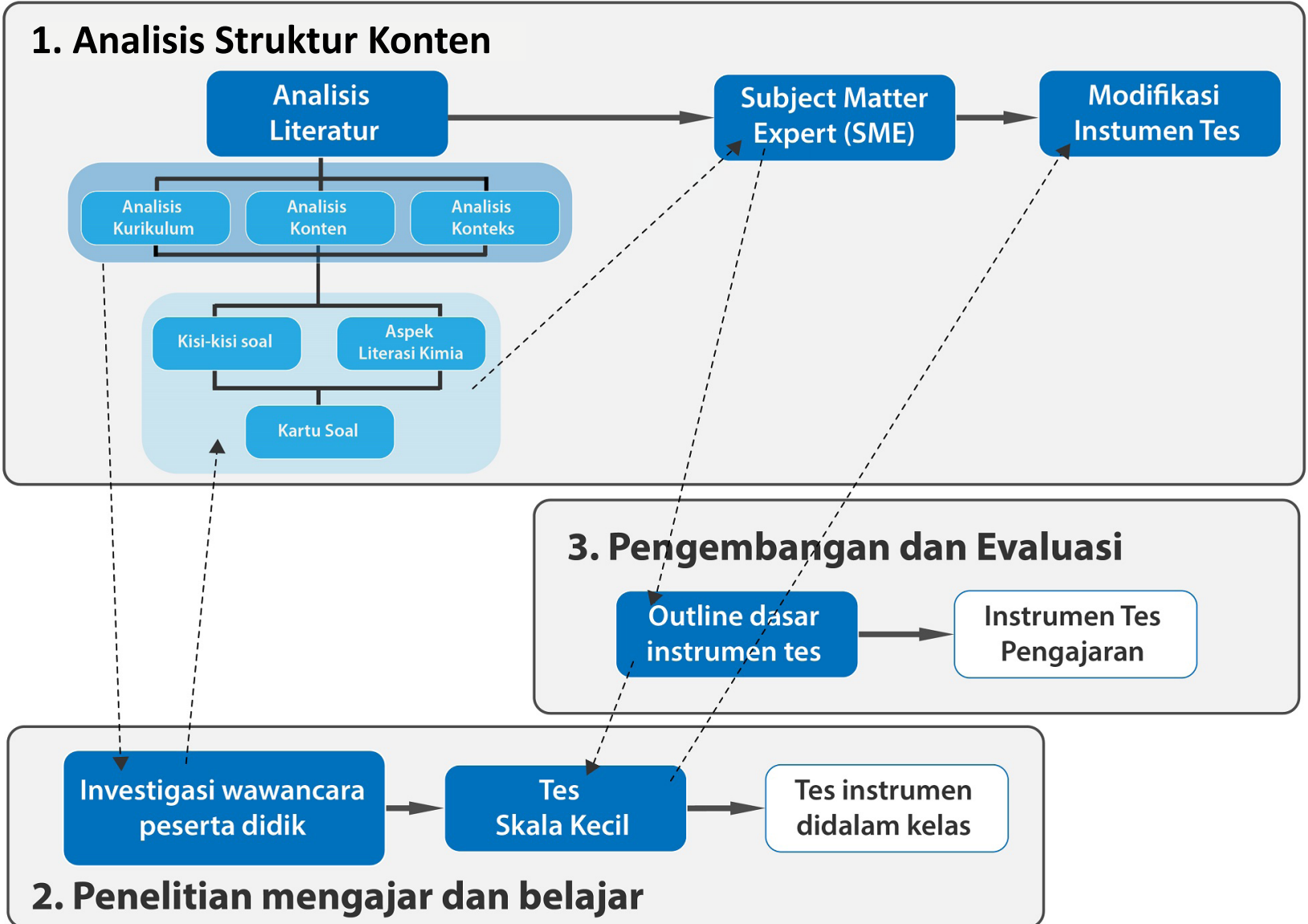

Keterangan : Tahap yang dilakukan

Gambar 2. Skema bagan MER yang dimodifikasi. 
tes yang diperoleh selanjutnya dianalisis untuk melihat nilai validitas dan reliabilitas secara empiris menggunakan model rasch dengan aplikasi winstep.

\section{HASIL DAN DISKUSI}

\subsection{Analisis Struktur Konten}

Pada analisis struktur konten dilakukan beberapa tahapan, diantaranya analisis silabus, analisis konten, dan analisis konteks. Pada tahap pertama dilakukan analisis silabus pada materi Ikatan Kimia menggunakan silabus kimia kurikulum 2013. Pada tahap ini dilakukan penurunan Kompetensi Dasar (KD) menjadi Indikator Pencapaian Kompetensi (IPK) pada materi Ikatan Kimia. Berdasarkan analisis KD di hasilkan delapan IPK pada materi ikatan kimia.

Selanjutnya pada tahap kedua dilakukan analisis konten pada materi ikatan kimia dengan menggunakan beberapa buku kimia universitas. Pada tahap ini buku kimia universitas yang digunakan adalah Chemistry karangan Whitten, dkk; Chemistry the molecular nature of matter karangan Jepersen, Brady, Hyslop; dan kimia dasar karangan Syukri. Tujuan analisis konten adalah untuk memperjelas konsep sains dan struktur konten dari sudut pandang ahli, hal ini perlu dilakukan karena beberapa buku teks sains menyajikan pengetahuan ilmiah secara abstrak dan padat yang dapat membuat miskonsepsi pada peserta didik ${ }^{[21]}$.

Pada tahap terakhir dilakukan analisis konteks yang bertujuan untuk menerapkan konteks pada materi ikatan kimia dengan peristiwa atau isu yang berkembang di kehidupan sehari-hari. Pada tahap ini analisis konteks dilakukan dengan berpatokan dengan jurnal atau artikel ilmiah.

\subsection{Investigasi Wawancara Peserta Didik}

Investigasi wawancara terhadap peserta didik dilakukan untuk melihat perspektif peserta didik terhadap pemahaman konsep, menyelidiki minat dan sikap peserta didik terhadap materi ikatan kimia. Pada tahap ini investigasi wawancara terhadap peserta didik dilakukan dengan berpatokan pada penelitian terdahulu (terdapat pada beberapa artikel). Berdasarkan hasil investigasi didapat bahwa peserta didik kesulitan memahami materi ikatan kimia karena materi ini bersifat abstrak, proses pembelajaran hanya fokus pada aspek konten saja, dan kurangnya keterkaitan materi ini dengan isu-isu atau peristiwa di kehidupan seharihari membuat peserta didik tidak terlalu berminat dalam mempelajari materi ikatan kimia.

\subsection{Penyusunan Instrumen Tes}

Pada tahapan ini dilakukan penyusunan instrumen tes yang disusun berdasarkan kisi-kisi soal dan aspek literasi kimia membentuk kartu soal. Kisi-kisi soal dalam penyusunannya berpatokan pada hasil analisis kurikulum, analisis konten, analisis konteks, dan hasil investigasi wawancara peserta didik. Pada kisi-kisi soal terdapat KD, IPK, indikator soal, aspek literasi kimia (konten, konteks, HOLS, dan afektif), level kognitif dan level pengetahuan (berdasarkan taksonomi bloom), bentuk soal (esai), dan nomor soal.

Kemudian berdasarkan kisi-kisi soal dan aspek literasi kimia (konten, konteks, HOLS, dan sikap) dibentuk kartu soal. Pada kartu soal terdapat wacana soal, pertanyaan soal, dan rubrik penilaian. Rubrik penilaian dilengkapi dengan jawaban soal, level literasi kimia, dan skor.

\subsection{Validasi Konten oleh Subject Matter Expert (SME)}

Pada tahap ini dilakukan validitas konten bersama lima orang validator yang terdiri dari dua orang dosen jurusan kimia FMIPA Universitas Negeri Padang dan tiga orang guru kimia SMA. Instrumen penilaian soal literasi kimia terdiri dari 13 aspek yang mencakup aspek isi/konten, bahasa, konstruk, dan grafis. Hasil validitas soal dianalisis menggunakan model rasch dengan aplikasi minifac. Adapun hasil dari analisis menggunakan aplikasi minifac, informasi ini dapat dilihat pada Gambar 3.

Berdasarkan Gambar 2, dapat dilihat persebaran kesesuaian butir soal dengan aspek penilaian instrumen berdasarkan penilaian validator. Kolom pertama pada Gambar 2 menunjukkan kolom measure yang memiliki skala logit dengan rentang -6 sampai +2 . Kolom kedua menunjukkan kolom soal yang menjelaskan kualitas soal yang dinilai oleh validator, butir soal yang menempati posisi paling atas merupakan soal yang memiliki kualitas yang baik berdasarkan penilaian validator, yaitu butir soal 2.1. Selanjutnya kolom ketiga merupakan kolom aspek penilaian instrumen, aspek penilaian yang menempati posisi paling atas merupakan aspek penilaian yang paling sulit dicapai/dipenuhi oleh soal menurut validator, yaitu A2. Sedangkan aspek penilaian yang paling mudah dicapai/dipenuhi soal menurut validator, yaitu A5. Terakhir kolom keempat merupakan kolom penguji, penguji AD dan ED menempati posisi paling atas yang menunjukkan penguji yang paling sukar dalam memberikan nilai, sedangkan penguji SA menempati posisi paling bawah yang menunjukkan penguji yang mudah memberikan nilai. Hasil dari analisis pengukuran penguji dengan menggunakan model rasch, informasi ini dapat dilihat pada Tabel 1.

Tabel 1. Ringkasan hasil analisis pengukuran penguji menggunakan model rasch.

\begin{tabular}{c|c|c|c}
$\begin{array}{c}\text { Strata } \\
\text { Value }\end{array}$ & $\begin{array}{c}\text { Relia- } \\
\text { bilitas }\end{array}$ & $\begin{array}{c}\text { Exact } \\
\text { Agree- } \\
\text { ments }\end{array}$ & $\begin{array}{c}\text { Expected } \\
\text { Agree- } \\
\text { ments }\end{array}$ \\
\hline 3,21 & 0,82 & $86,8 \%$ & $87,7 \%$
\end{tabular}

Tabel 1 menyatakan bahwa indeks reliabilitas penguji adalah 0,82 yang termasuk dalam kategori baik. Indeks reliabilitas ini menunjukkan keandalan penguji dalam memberikan penilaian pada setiap item butir soal. Kemudian, strata value yang diperoleh berada pada nilai di atas 3 yaitu sebesar 
3,21 yang menunjukkan penilaian penguji reliabel. Terakhir, hasil analisis menunjukkan bahwa exact agreements yang diperoleh adalah 86,8\% yang menunjukkan berdasarkan perhitungan jumlah persetujuan penguji terhadap instrumen tinggi. Hasil ini cenderung tidak jauh dari hasil analisis expected agreements yang memperoleh hasil $87,7 \%$ yang menunjukkan hasil perhitungan tidak terlalu jauh dari hasil yang diperkirakan oleh model.

\subsection{Outline Dasar Instrumen Tes}

Instrumen literasi kimia yang dikembangkan dengan model MER terdiri dari 5 tema soal dengan jumlah keseluruhan butir soal sebanyak 13 butir soal. Masing-masing tema soal disusun berdasarkan kisi-kisi soal, aspek literasi kimia (konten, konteks, HOLS, dan sikap) serta rubrik penilaian yang disusun berdasarkan level literasi kimia.

Aspek literasi kimia pada instrumen literasi kimia yang dikembangkan yaitu pertama, aspek konten yang merupakan konsep/materi ikatan kimia yang terdapat dalam soal. Kedua, aspek konteks merupakan penerapan konsep/ materi ikatan kimia pada peristiwa atau isuisu yang berkembang di kehidupan seharihari. ketiga, aspek HOLS (High Order Learning Skills) merupakan kemampuan mengidentifikasi pertanyaan dari informasi yang berkaitan dengan konten dan konteks serta dapat menganalisis

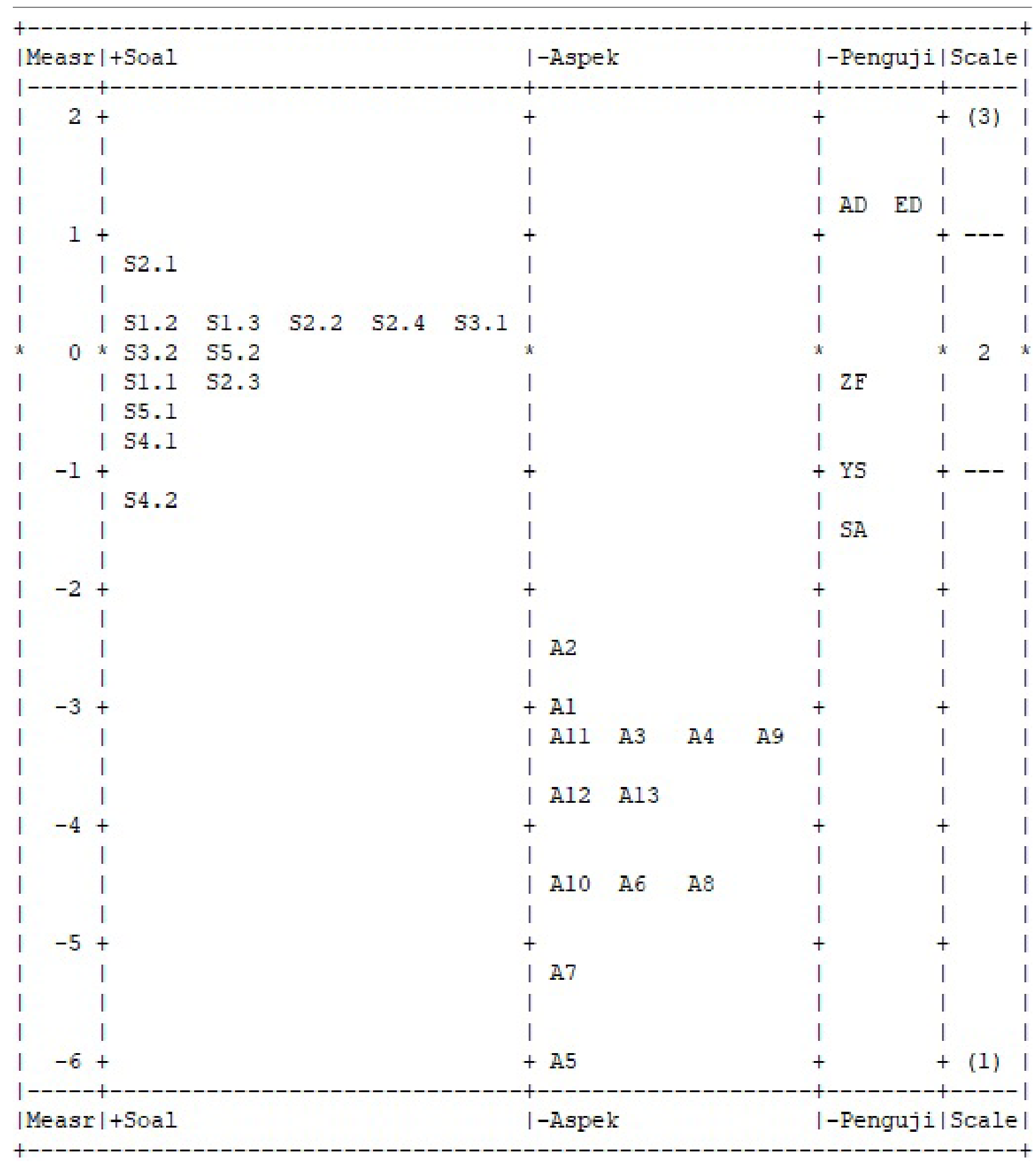

Gambar 3. Wright Map. 
Tabel 2. Tema soal 1.

\section{Tema: Kenapa Air Laut Asin? (Bagian 1)}

\section{Wacana Soal}

Lembaga Kelautan dan Atmosfer Nasional (NOAA) berpendapat asinnya air laut bermula dari:
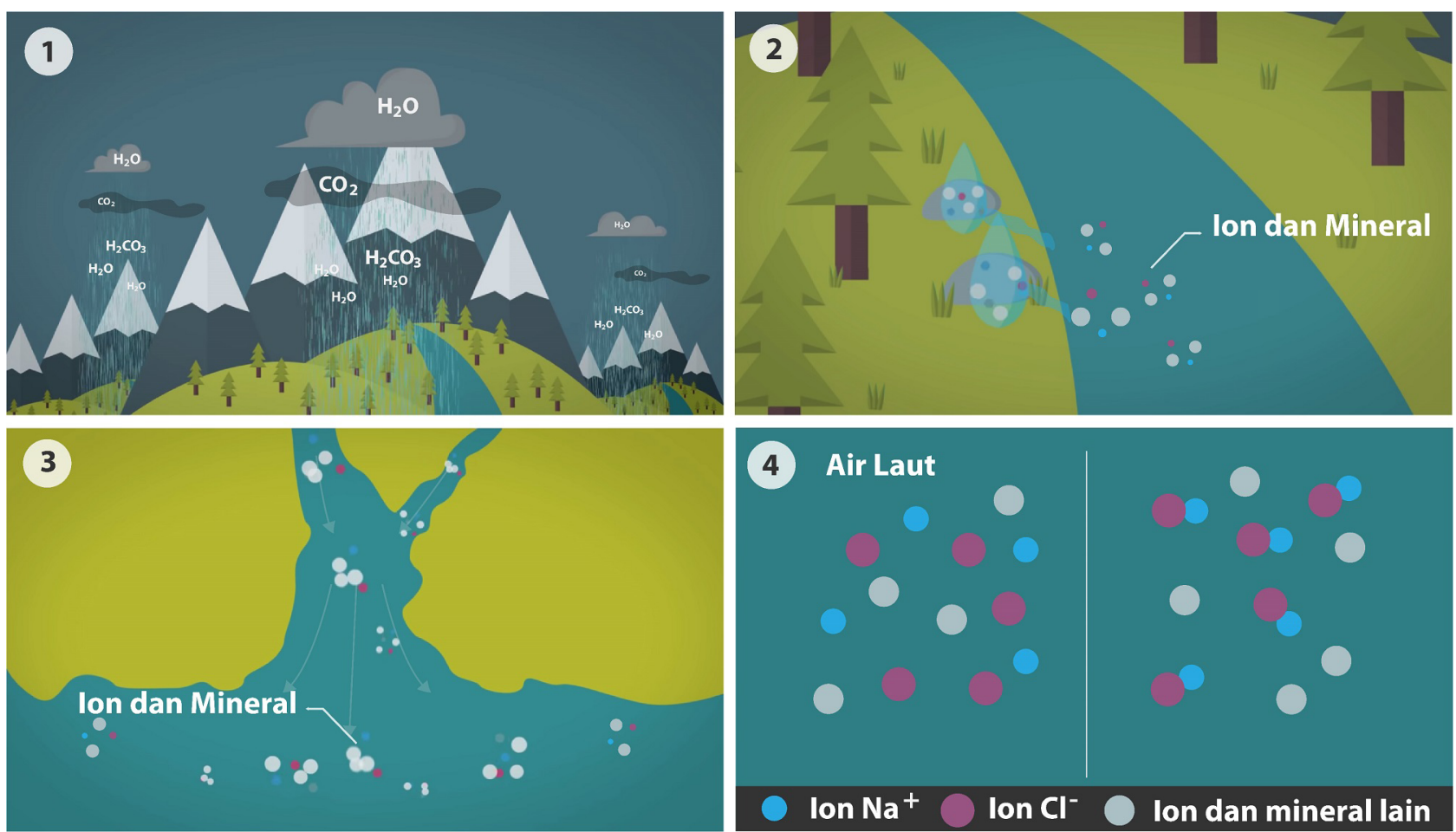

Pertama, air hujan yang jatuh ke daratan bertemu dengan karbondioksida $\left(\mathrm{CO}_{2}\right)$ di udara yang menyebabkan air hujan mengandung asam karbonat $\left(\mathrm{H}_{2} \mathrm{CO}_{3}\right)$ dan bersifat sedikit asam. Kedua, Asam yang terkandung dalam hujan akan memecah bebatuan di daratan dan menghasilkan ion-ion. Ketiga, Ion-ion yang terbentuk akan terbawa oleh air hujan menuju ke sungai-sungai dan terus menuju lautan. Ion-ion yang umumnya terkandung di air laut, dapat dilihat pada tabel di bawah ini.

\begin{tabular}{c|c|c} 
Ion & Jumlah Kandungan & Jenis Unsur \\
\hline $\mathrm{Cl}^{-}$ & $55 \%$ & Non Logam \\
\hline $\mathrm{Na}^{+}$ & $31 \%$ & Logam \\
\hline $\mathrm{SO}_{4}^{-2}$ & $8 \%$ & Non Logam \\
\hline $\mathrm{Mg}^{2+}$ & $4 \%$ & Logam \\
\hline $\mathrm{Ca}^{2+}$ & $1 \%$ & Logam \\
\hline $\mathrm{K}^{+}$ & $1 \%$ & Logam
\end{tabular}

Terakhir, Ion-ion akan terkumpul di lautan, membuat keberadaan ion-ion ini akan dominan sehingga membuat air laut menjadi asin. Banyak diantaranya akan bereaksi membentuk ikatan kimia dan menghasilkan senyawa garam. Salah satu contoh ion $\mathrm{Na}^{+}$dan $\mathrm{Cl}^{-}$bertemu dan membentuk senyawa garam $\mathrm{NaCl}$.

\section{Soal}

1.1. Ion-ion akan berkumpul di lautan dan membentuk ikatan kimia menjadi senyawa garam (salah satu contohnya garam $\mathrm{NaCl}$ ). Jelaskan jenis ikatan kimia apa yang terbentuk pada senyawa $\mathrm{NaCl}$, serta gambarkanlah struktur lewisnya!

1.2. Beberapa ion yang terkandung di air laut adalah $\mathrm{Mg}^{2+}, \mathrm{Cl}^{-}, \mathrm{K}^{+}$, dan $\mathrm{SO}_{4}^{-2}$. Jelaskan 2 kemungkinan senyawa garam yang terbentuk dari beberapa ion tersebut beserta proses pembentukannya dalam bentuk struktur lewis! 
permasalahan yang terjadi. Terakhir aspek sikap yang merupakan kemampuan dalam memberikan sikap dalam menyelesaikan permasalahan yang berkaitan dengan fenomena atau isu tentang ikatan kimia $^{[17]}$.

Selanjutnya masing-masing butir soal dilengkapi dengan rubrik penilaian yang disusun berdasarkan level literasi kimia. Penentuan level literasi kimia disesuaikan dengan tuntutan dari indikator soal yang harus dicapai. Level literasi kimia terdiri dari lima level yaitu scientific illiteracy: pada tingkat ini seseorang tidak dapat memberikan jawaban atau jawaban yang diberikan salah; nominal scientific literacy: pada tingkat ini seseorang hanya dapat memberikan jawaban berupa nama konsep namun tidak dapat menjelaskan konsep tersebut secara bermakna; functional scientific literacy; pada tingkat ini seseorang dapat menjelaskan konsep namun pemahamannya akan konsep masih terbatas; conceptual scientific literacy: pada tingkat ini seseorang sudah dapat menjelaskan konsep dengan baik serta dapat mengaitkan hubungan antar konsep satu dengan konsep lainnya; terakhir multi-dimensional scientific literacy; pada tingkat ini seseorang selain dapat menjelaskan konsep dengan baik serta mengaitkan hubungan antar konsep, seseorang tersebut juga dapat menghubungkan konsep-konsep sains dengan permasalahan di kehidupan sehari-hari seperti keterkaitan antara perkembangan sains, teknologi dan sosial.

Pada instrumen literasi kimia pada materi ikatan kimia yang dikembangkan, dirancang 5 tema soal. Tema pertama tentang kenapa air laut asin dengan jawaban tertinggi pada rubrik penilaian terdapat pada level conceptual scientific literacy. Pada tema ini terdapat 3 butir soal. Tema kedua tentang hujan asam dengan jawaban tertinggi pada rubrik penilaian terdapat pada level conceptual scientific literacy. Pada tema ini terdapat 4 butir soal. Tema ketiga tentang cairan pembersih porselen dengan jawaban tertinggi pada rubrik penilaian terdapat pada level functional scientific literacy. Pada tema

Tabel 3. Tema soal 1.

\section{Tema: Kenapa Air Laut Asin? (Bagian 2)}

\section{Wacana Soal}

$\mathrm{NaCl}$ (Natrium Clorida) atau juga dikenal di pasaran dengan nama garam dapur adalah senyawa garam yang berasal dari laut yang paling banyak digunakan oleh manusia di kehidupan sehari-hari.

Namun menurut penelitian yang dilakukan pada tahun 2018 oleh greenpeace asian timur, 36 dari 39 merek garam di seluruh dunia mengandung senyawa mikroplastik (potongan plastik berukuran kecil) di dalamnya. Hal ini disebabkan karena pencemaran laut oleh limbah-limbah plastik yang berasal dari aktivitas manusia.

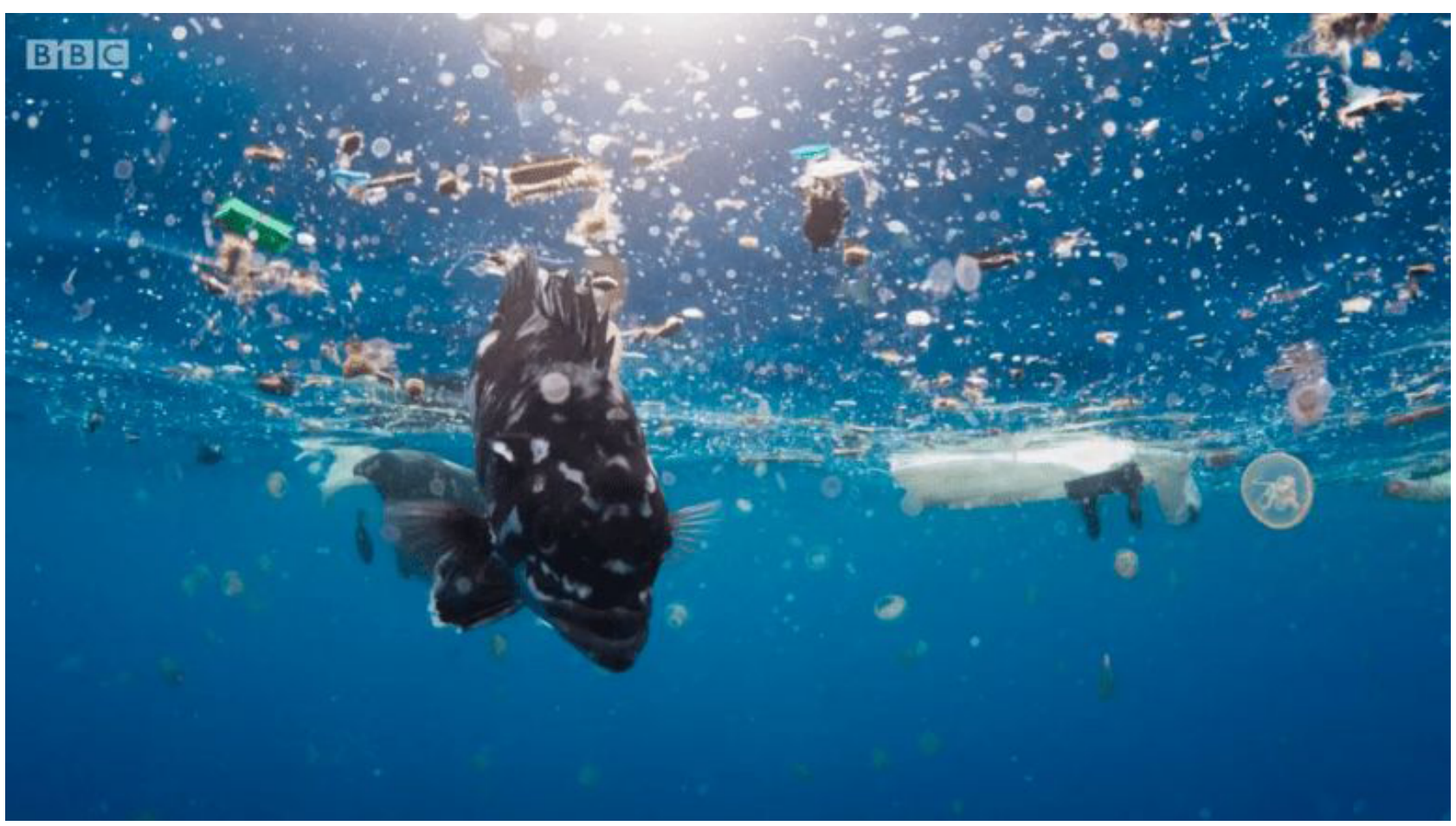

Garam yang mengandung mikroplastik dapat mengakibatkan gangguan fungsi ginjal dan hati sehingga menimbulkan suatu penyakit bagi manusia. Selain itu pencemaran senyawa mikroplastik di laut juga dapat memberikan dampak buruk bagi ekosistem laut.

\section{Soal}

1.3. Pencemaran senyawa mikroplastik di laut memberikan dampak buruk bagi manusia maupun ekosistem di laut. Untuk mengatasi hal tersebut, tindakan apa yang harus kamu lakukan? 
Tabel 4. Rubrik penilaian soal.

\begin{tabular}{|c|c|}
\hline Level Literasi & Jawaban \\
\hline Scientific Illiteracy & Jawaban Salah. \\
\hline $\begin{array}{l}\text { Nominal Scientific } \\
\text { Literacy }\end{array}$ & Ikatan yang terbentuk adalah ikatan ion. \\
\hline $\begin{array}{l}\text { Functional Scientific } \\
\text { Literacy }\end{array}$ & $\begin{array}{l}\text { Ikatan yang terbentuk adalah ikatan ion, karena terjadinya interaksi elektrostatik } \\
\text { antara ion positif dan ion negatif membentuk senyawa ion. }\end{array}$ \\
\hline $\begin{array}{l}\text { Conceptual Scientific } \\
\text { Literacy }\end{array}$ & $\begin{array}{l}\text { Ikatan yang terbentuk adalah ikatan ion, karena terjadinya interaksi elektrostatik } \\
\text { antara ion positif dan ion negatif membentuk senyawa ion. } \\
\text { Bentuk reaksinya dalam bentuk struktur lewis adalah } \\
\mathrm{Na} \odot \cdot \ddot{\mathrm{C} l}: \longrightarrow \mathrm{Na}^{+}+[: \ddot{\mathrm{Cl}}:]^{-} \\
\begin{array}{l}\mathrm{Na} \text { melepas } 1 \text { elektron terluar dan } \mathrm{Cl} \text { menangkap } 1 \text { elektron sehingga terjadi } \\
\text { transfer elektron dan membuat gaya tarik menarik elektrostatis antara } \mathrm{Na} \text { yang } \\
\text { bermuatan positif dengan } \mathrm{Cl} \text { bermuatan negatif sehingga terbentuk senyawa } \mathrm{NaCl}\end{array}\end{array}$ \\
\hline
\end{tabular}

Tabel 5. Rubrik penilaian soal.

\begin{tabular}{|c|c|}
\hline Level Literasi & Jawaban \\
\hline Scientific Illiteracy & Jawaban Salah. \\
\hline $\begin{array}{l}\text { Nominal Scientific } \\
\text { Literacy }\end{array}$ & $\begin{array}{l}\text { Kemungkinan senyawa yang terbentuk, } \\
\mathrm{MgCl}_{2} \\
\mathrm{~K}_{2} \mathrm{SO}_{4} \\
\mathrm{MgSO}_{4} \\
\mathrm{KCl}\end{array}$ \\
\hline $\begin{array}{l}\text { Functional Scientific } \\
\text { Literacy }\end{array}$ & 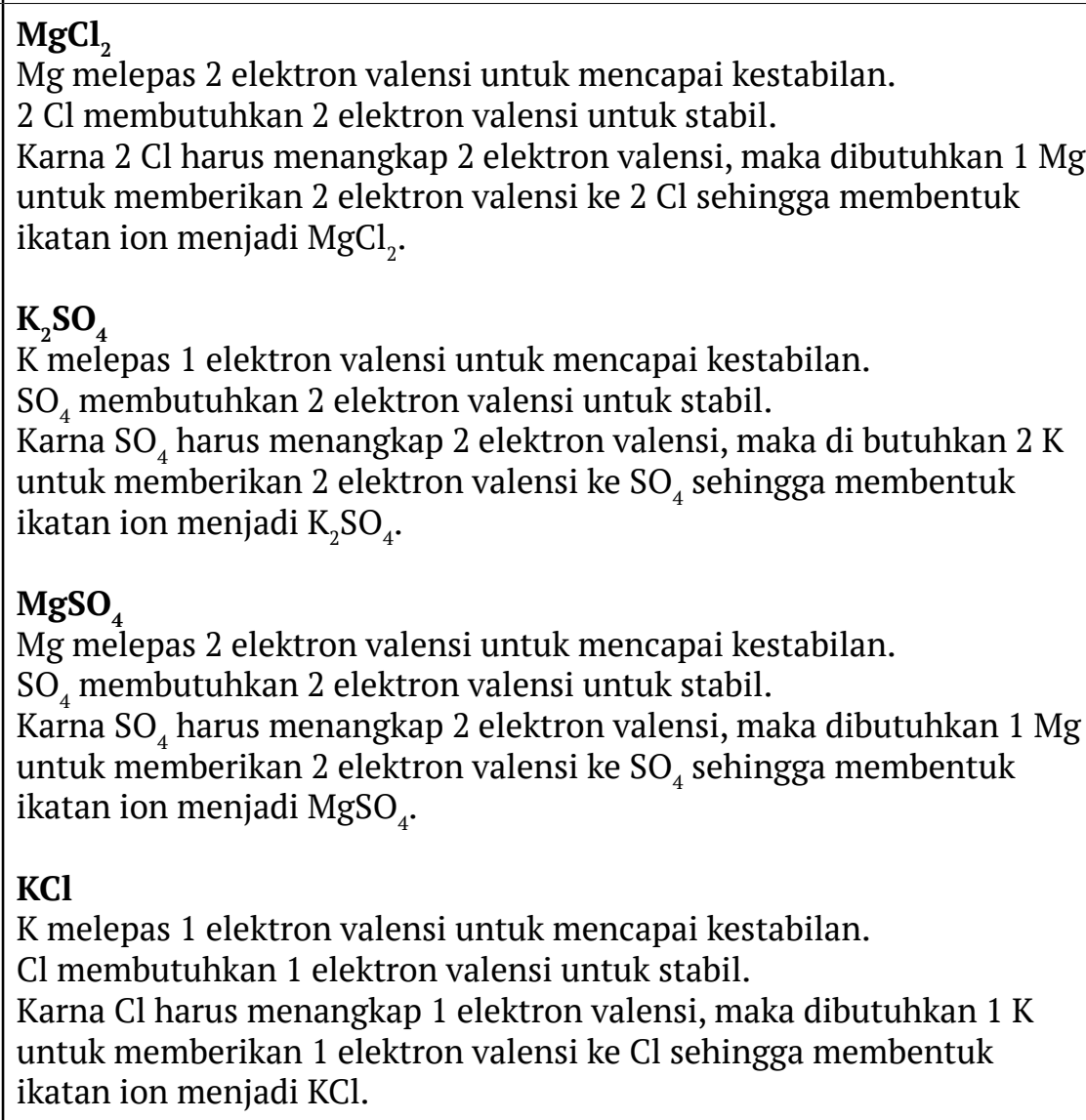 \\
\hline
\end{tabular}


Tabel 5. Rubrik penilaian soal (lanjutan).

\begin{tabular}{l|l} 
Level Literasi & Jawaban \\
\hline Conceptual Scientific & $\mathbf{M g C l}_{2}$ \\
Literacy & Mg melepas 2 elektron valensi untuk mencapai kestabilan. \\
& 2 Cl membutuhkan 2 elektron valensi untuk stabil. \\
Karna 2 Cl harus menangkap 2 elektron valensi, maka di butuhkan 1 $\mathrm{Mg}$ \\
untuk memberikan 2 elektron valensi 2 ke Cl sehingga membentuk \\
ikatan ion menjadi $\mathrm{MgCl}_{2}$.
\end{tabular}

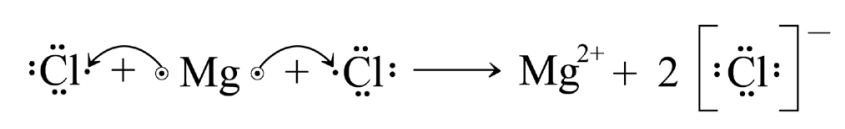

$\mathrm{K}_{2} \mathrm{SO}_{4}$

$\mathrm{K}$ melepas 1 elektron valensi untuk mencapai kestabilan.

$\mathrm{SO}_{4}$ membutuhkan 2 elektron valensi untuk stabil.

Karna $\mathrm{SO}_{4}$ harus menangkap 2 elektron valensi, maka dibutuhkan $2 \mathrm{~K}$

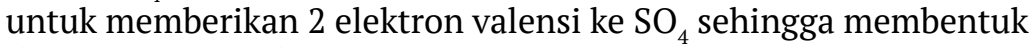

ikatan ion menjadi $\mathrm{K}_{2} \mathrm{SO}_{4}$.

Bentuk reaksinya dalam bentuk struktur lewis adalah

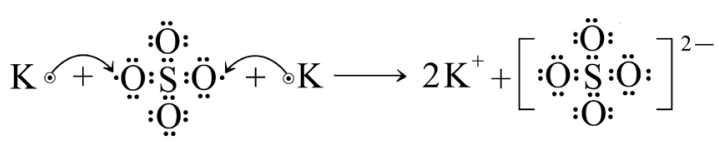

$\mathrm{MgSO}_{4}$

$\mathrm{Mg}$ melepas 2 elektron valensi untuk mencapai kestabilan.

$\mathrm{SO}_{4}$ membutuhkan 2 elektron valensi untuk stabil.

Karna $\mathrm{SO}_{4}$ harus menangkap 2 elektron valensi, maka dibutuhkan $1 \mathrm{Mg}$

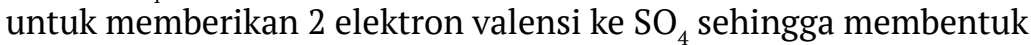

ikatan ion menjadi $\mathrm{MgSO}_{4}$.

Bentuk reaksinya dalam bentuk struktur lewis adalah

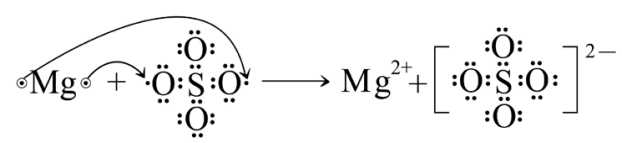

KCl

K melepas 1 elektron valensi untuk mencapai kestabilan.

$\mathrm{Cl}$ membutuhkan 1 elektron valensi untuk stabil.

Karna $\mathrm{Cl}$ harus menangkap 1 elektron valensi, maka dibutuhkan $1 \mathrm{~K}$ untuk

memberikan 1 elektron valensi ke $\mathrm{Cl}$ sehingga membentuk ikatan ion menjadi $\mathrm{KCl}$.

Bentuk reaksinya dalam bentuk struktur lewis adalah

$$
\mathrm{K} \odot+\stackrel{\mathrm{C}}{ } 1: \longrightarrow \mathrm{K}^{+}+[: \ddot{\mathrm{C}} 1:]^{-}
$$

ini terdapat 2 butir soal. Tema keempat tentang pemanfaatan larutan garam sebagai pengganti tembaga dalam kabel listrik dengan jawaban tertinggi pada rubrik penilaian terdapat pada level functional scientific literacy. Pada tema ini terdapat 2 butir soal. Tema kelima tentang panel surya dengan jawaban tertinggi pada rubrik penilaian terdapat pada level functional scientific literacy. Pada tema ini terdapat 2 butir soal.

Rancangan soal literasi kimia pada materi ikatan kimia yang berjumlah 5 tema soal dengan jumlah keseluruhan butir soal sebanyak 13 butir soal. Contoh rancangan soal literasi kimia ialah tema soal 1 yang terbagi pada dua bagian, 
Tabel 6. Rubrik penilaian soal.

\begin{tabular}{l|l} 
Level Literasi & Jawaban \\
\hline Scientific Illiteracy & Jawaban Salah. \\
\hline Nominal Scientific & 1. Mengurangi pemakaian plastik dalam kehidupan sehari-hari \\
Literacy & 2. Menjaga kebersihan pantai dan laut dari sampah \\
& 3. Tidak membuang sampah sembarangan \\
& 4. Mendaur ulang sampah plastik \\
& 5. Ikut aksi peduli lingkungan
\end{tabular}

informasi ini dapat dilihat pada Tabel 2 dan Tabel 3 serta soal tema 4 yang mana informasi ini dapat dilihat pada Tabel 7 .

Tema soal 1 tentang kenapa air laut asin bagian 1 memiliki 3 butir soal, yang mana masingmasing soal memiliki indikator soal. Indikator soal 1.1 yaitu peserta didik dapat menjelaskan jenis ikatan kimia dari wacana yang diberikan; indikator soal 1.2 yaitu peserta didik dapat menuliskan proses pembentukan dua senyawa ion dari empat kombinasi ion yang diberikan; indikator soal 1.3 peserta didik dapat memberikan pendapat atau sikap terhadap wacana yang diberikan. Pada tema soal 1 terdapat aspek konten tentang materi/konsep ikatan ion yang dianalisis menggunakan buku kimia universitas dan aspek konteks tentang kenapa air laut asin yang dianalisis menggunakan artikel ilmiah. Aspek HOLS (High Order Learning Skills) pada tema soal 1 ini dapat dicapai oleh peserta didik dengan menganalisis informasi tentang proses pembentukan ion-ion di laut yang dijelaskan dalam wacana soal sehingga dapat memanfaatkan informasi tersebut untuk menyelesaikan soalsoal yang diberikan. Terakhir aspek sikap pada tema soal 1 ini dapat dicapai ketika peserta didik dapat memberikan sikap atau pendapatnya dalam menyelesaikan permasalahan yang terjadi di kehidupan sehari-hari, contohnya permasalahan pencemaran air laut yang diakibatkan oleh senyawa mikroplastik.

Rubrik penilaian pada soal $1.1,1.2$ dan 1.3 disusun berdasarkan level literasi kimia. Soal 1.1 memiliki jawaban tertinggi pada level conceptual scientific literacy, soal 1.2 memiliki jawaban tertinggi pada level conceptual scientific literacy dan terakhir soal 1.3 memiliki jawaban tertinggi pada level nominal scientific literacy. Rubrik penilaian soal 1.1, 1.2, dan 1.3 informasi ini dapat dilihat pada Tabel 4, Tabel 5 dan Tabel 6.

Pada rubrik penilaian soal 1.1 jawaban soal dikatakan memiliki level scientific illiteracy ketika peserta didik tidak dapat menyebutkan nama konsep ikatan ion atau jawaban yang diberikan salah; level nominal scientific literacy ketika peserta didik hanya dapat menyebutkan nama konsep yaitu ikatan ion tetapi tidak dapat menjelaskan pengertian ikatan ion lebih lanjut; level functional scientific literacy ketika peserta didik dapat menyebutkan nama konsep yaitu ikatan ion serta dapat menjelaskan pengertian ion lebih lanjut; level conceptual scientific literacy ketika peserta didik dapat menyebutkan dan menjelaskan pengertian ikatan ion dengan baik serta juga dapat menghubungkan konsep ikatan ion dengan konsep lainnya, contoh jawaban pada rubrik penilaian adalah menghubungkan konsep ikatan ion dengan konsep konfigurasi elektron dalam menjelaskan proses pembentukan ikatan ion pada senyawa $\mathrm{NaCl}$.

Pada rubrik penilaian soal 1.2 jawaban soal dikatakan memiliki level scientific illiteracy ketika peserta didik tidak dapat menyebutkan kemungkinan senyawa ion yang terbentuk dari beberapa ion-ion yang diberikan atau jawaban yang diberikan salah; level nominal scientific literacy ketika peserta didik hanya dapat menyebutkan kemungkinan senyawa ion yang terbentuk dari beberapa ion-ion yang diberikan yaitu $\mathrm{MgCl}_{2}, \mathrm{~K}_{2} \mathrm{SO}_{4}$, $\mathrm{MgSO}_{4}$, dan $\mathrm{KCl}$ tetapi tidak dapat menjelaskan lebih lanjut proses pembentukan senyawa-senyawa tersebut; level functional scientific literacy ketika peserta didik dapat menyebutkan kemungkinan senyawa ion yang terbentuk dari beberapa ionion yang diberikan yaitu $\mathrm{MgCl}_{2}, \mathrm{~K}_{2} \mathrm{SO}_{4}, \mathrm{MgSO}_{4}$, dan $\mathrm{KCl}$ serta dapat menjelaskan lebih lanjut proses pembentukan senyawa-senyawa tersebut; level conceptual scientific literacy ketika peserta didik dapat menyebutkan kemungkinan senyawa ion yang terbentuk dan menjelaskan proses pembentukannya dengan baik serta juga dapat menghubungkan konsep proses pembentukan ikatan ion dengan konsep lain. Contoh jawaban pada rubrik penilaian adalah menghubungkan konsep ikatan ion dengan konsep konfigurasi elektron dalam menjelaskan proses pembentukan kemungkinan senyawa ion yang terbentuk dari beberapa ion yang diberikan.

Terakhir rubrik penilaian soal 1.3 jawaban soal dikatakan memiliki level scientific illiteracy ketika peserta didik tidak dapat memberikan sikap atau pendapat dalam menyelesaikan permasalahan yang diberikan atau jawaban yang diberikan salah dan level nominal scientific literacy ketika peserta didik dapat memberikan sikap atau pendapat dalam menyelesaikan permasalahan yang diberikan.

Tema soal 4 tentang pemanfaatan larutan garam sebagai pengganti tembaga dalam kabel listrik memiliki 2 butir soal, salah satunya soal 4.1. Indikator soal 4.1 yaitu peserta didik dapat 
Tabel 7. Tema soal 2.

\section{Tema: Kenapa Air Laut Asin? (Bagian 1)}

Penggunaan kabel listrik pada saat ini masih menggunakan kabel tembaga. Penggunaan tembaga dikarenakan tembaga memiliki sifat penghantar listrik dan panas yang tinggi serta memiliki ketahanan akan korosi yang baik pula. Karena sifatnya, 60\% penggunaan tembaga digunakan sebagai kabel listrik. Bukan tidak mungkin tembaga sewaktu-waktu tembaga akan semakin berkurang dan habis.

Penelitian yang dilakukan oleh Syafita rezki, dkk pada tahun 2019 yaitu tentang "Pemanfaatan Air Larutan Garam Sebagai Kabel Penghantar Listrik Pengganti Tembaga” merupakan salah satu inovasi yang dapat dilakukan. Berdasarkan penelitiannya larutan garam $(\mathrm{NaCl})$ dapat menghantarkan arus listrik sebanding dengan jumlah massa garam pada larutan tersebut. Perbandingan daya hantar listrik antara tembaga, larutan garam, dan air dapat dilihat pada tabel dibawah ini.

\begin{tabular}{c|c|c} 
Tembaga $(\mathbf{C u})$ & Larutan garam $(\mathbf{N a C l})$ & Air $\left(\mathbf{H}_{2} \mathbf{0}\right)$ \\
\hline 9,79 watt & 6,37 watt & 0,94 watt
\end{tabular}

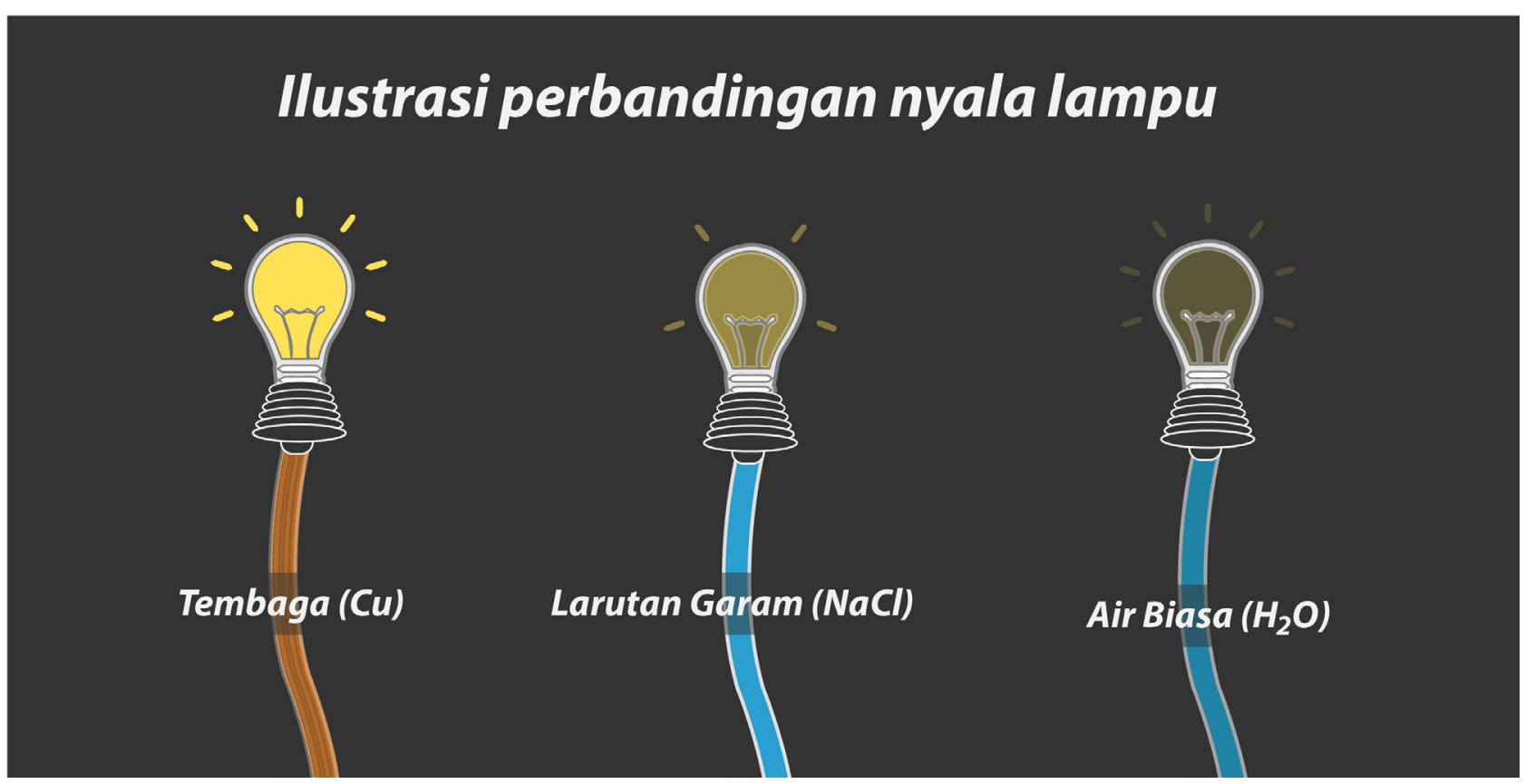

Listrik adalah energi yang dihasilkan oleh aliran elektron. Berdasarkan tabel diatas tembaga (Cu) lebih kuat menghantarkan elektron daripada larutan garam $(\mathrm{NaCl})$ dan Air $\left(\mathrm{H}_{2} \mathrm{O}\right)$.

\section{Soal}

4.1. Berdasarkan tabel diatas, kabel yang berisi tembaga $(\mathrm{Cu})$ menghantarkan listrik paling kuat dan kabel yang berisi air $\left(\mathrm{H}_{2} \mathrm{O}\right)$ menghantarkan listrik paling lemah. Hal ini dapat dipengaruhi oleh jenis ikatan masing-masing senyawa tersebut. Bandingkan masing-masing jenis ikatan kimia pada tembaga $(\mathrm{Cu})$, garam $(\mathrm{NaCl})$, dan air $\left(\mathrm{H}_{2} \mathrm{O}\right)$, kemudian jelaskan kenapa daya hantar listrik $\mathrm{Cu}>\mathrm{NaCl}>\mathrm{H}_{2} \mathrm{O}$ berdasarkan jenis ikatannya!

membandingkan senyawa mana yang memiliki sifat penghantar listrik lebih baik antara senyawa ion, senyawa kovalen dan senyawa logam dari beberapa senyawa yang diberikan. Pada tema soal 4 terdapat aspek konten tentang materi/konsep ikatan ion, ikatan kovalen, dan ikatan logam yang dianalisis menggunakan buku kimia universitas dan aspek konteks tentang pemanfaatan larutan garam sebagai pengganti tembaga dalam kabel listrik yang dianalisis menggunakan artikel ilmiah. Aspek HOLS (High Order Learning Skills) pada tema soal 4 ini dapat dicapai oleh peserta didik dengan menganalisis informasi tentang perbandingan daya hantar listrik dengan jenis ikatan masingmasing senyawa dalam wacana soal sehingga dapat memanfaatkan informasi tersebut untuk menyelesaikan soal-soal yang diberikan.

Rubrik penilaian pada soal 4.1 disusun berdasarkan level literasi kimia. Soal 4.1 memiliki jawaban tertinggi pada level functional scientific literacy. Rubrik penilaian soal 4.1 informasi ini dapat dilihat pada Tabel 8 .

Pada rubrik penilaian soal 4.1 jawaban soal dikatakan memiliki level scientific illiteracy ketika peserta didik tidak dapat menyebutkan jenis ikatan kimia masing-masing senyawa yang diberikan 
Tabel 8. Rubrik penilaian soal.

\begin{tabular}{l|l} 
Level Literasi & Jawaban \\
\hline Scientific Illiteracy & Jawaban Salah \\
Literacy & $\begin{array}{l}\text { Tembaga }(\mathrm{Cu}) \text { memiliki jenis ikatan kimia yaitu ikatan logam. } \\
\text { Garam }(\mathrm{NaCl}) \text { memiliki jenis ikatan kimia yaitu ikatan ion. } \\
\text { Air }\left(\mathrm{H}_{2} \mathrm{O}\right) \text { memiliki jenis ikatan kimia yaitu ikatan kovalen. }\end{array}$ \\
\hline Functional Scientific & $\begin{array}{l}\text { Tembaga }(\mathrm{Cu}) \text { memiliki jenis ikatan kimia yaitu ikatan logam. } \\
\text { Karena ikatan logam memiliki lautan elektron yang berikatan dengan ion logam } \\
\text { positif, sehingga ketika listrik dialirkan lautan elektron akan bergerak bebas } \\
\text { dan menghantarkan arus listrik. }\end{array}$ \\
$\begin{array}{l}\text { Garam (NaCl) memiliki jenis ikatan kimia yaitu ikatan ion. } \\
\text { Karena ikatan ion memiliki ikatan antara ion negatif dengan ion positif, ketika } \\
\text { larut dalam air ion negatif dan ion positif akan terpisah dan bergerak bebas } \\
\text { dan ketika dialirkan arus listrik ion negatif akan mengikat elektron } \\
\text { dan menghantarkan arus listrik. }\end{array}$ \\
$\begin{array}{l}\text { Air }\left(\mathrm{H}_{2} \mathrm{O}\right) \text { memiliki jenis ikatan kimia yaitu ikatan kovalen. } \\
\text { Ikatan kovalen menghantarkan listrik dengan sangat lemah, adapun elektron } \\
\text { yang dihantarkan karena gaya tarik elektron oleh sifat kepolaran air. Keelektrone- } \\
\text { gatifan atom O akan mengikat elektron dan mengantarkannya, tetapi ikatannya } \\
\text { sangat lemah yang membuat tidak banyak elektron yang dapat dihantarkan. }\end{array}$
\end{tabular}

Tabel 9. Misfit order.

\begin{tabular}{c|c|r|c}
\multirow{2}{*}{ No. soal } & \multicolumn{2}{|c|}{ Outfit } & \multirow{2}{*}{$\begin{array}{c}\text { Pt. Mean } \\
\text { Corr }\end{array}$} \\
\cline { 2 - 3 } & MNSQ & ZSTD & \\
\hline 1.1 & 0,80 & $-0,57$ & 0,71 \\
\hline 1.2 & 0,92 & $-0,10$ & 0,72 \\
\hline 1.3 & 0,29 & $-9,59$ & 0,71 \\
\hline 2.1 & 1,02 & 0,16 & 0,62 \\
\hline 2.2 & 0,92 & $-0,17$ & 0,71 \\
\hline 2.3 & 0,56 & $-0,94$ & 0,77 \\
\hline 2.4 & 0,78 & 0,17 & 0,62 \\
\hline 3.1 & 0,23 & $-0,82$ & 0,75 \\
\hline 3.2 & 0,60 & $-0,61$ & 0,73 \\
\hline 4.1 & 1,47 & 1,47 & 0,54 \\
\hline 4.2 & 1,27 & 0,94 & 0,64 \\
\hline 5.1 & 1,22 & 0,79 & 0,30 \\
\hline 5.2 & 0,13 & $-0,93$ & 0,77
\end{tabular}

atau jawaban yang diberikan salah; level nominal scientific literacy ketika peserta didik hanya dapat menyebutkan jenis ikatan kimia masingmasing senyawa yang diberikan tetapi tidak dapat memberikan penjelasan lebih lanjut tentang hubungan jenis ikatan kimia dengan tingginya daya hantar listrik masing-masing senyawa tersebut; level functional scientific literacy ketika peserta didik dapat menyebutkan jenis ikatan kimia masing-masing senyawa yang diberikan serta

\begin{tabular}{|c|c|c|c|c|c|c|c|}
\hline & \multicolumn{2}{|c|}{ MODEL } & & \multicolumn{2}{|c|}{ INFIT } & \multicolumn{2}{|c|}{ OUTFIT } \\
\hline & MEASURE & S.E. & & MNSQ & ZSTD & MNSQ & ZSTD \\
\hline MEAN & .00 & .39 & & .98 & .03 & .79 & -.09 \\
\hline SEM & .60 & .04 & & .06 & .23 & .11 & .21 \\
\hline P.SD & 2.08 & .13 & & .21 & .80 & .40 & .74 \\
\hline S.SD & 2.16 & .13 & & .22 & .83 & .41 & .77 \\
\hline MAX. & 2.85 & .60 & & 1.22 & 1.12 & 1.47 & 1.47 \\
\hline MIN. & -2.99 & .28 & & .44 & -1.45 & .13 & -.94 \\
\hline REAL & & TION & 4.83 & Ite & $\mathrm{RE}$ & ABILI? & .96 \\
\hline MODEL & 2.04 & ATION & 5.01 & Ite & $\mathrm{RE}$ & ABILI & .96 \\
\hline
\end{tabular}

Gambar 4. Summary Statistic Item.

dapat memberikan penjelasan lebih lanjut tentang hubungan jenis ikatan kimia dengan tingginya daya hantar listrik masing-masing senyawa tersebut.

\subsection{Studi Empiris ke Sekolah}

Setelah memperoleh hasil validasi konten dan pembentukan outline dasar instrumen tes maka dilanjutkan dengan melakukan studi empiris, yaitu pengujian instrumen tes terhadap 59 orang peserta didik yang sudah mempelajari materi ikatan kimia. Hasil tes yang diperoleh selanjutnya dianalisis untuk melihat nilai validitas dan reliabilitas secara empiris menggunakan model rasch dengan aplikasi winstep. Informasi ini dapat dilihat pada Tabel 9 dan Gambar 4.

Nilai reliabilitas dikatakan termasuk kategori bagus apabila memiliki rentang nilai 0,81 sampai dengan 0,90, dan termasuk kategori bagus sekali apabila memiliki nilai > 0,91. Berdasarkan Gambar 4, hasil uji reliabilitas diperoleh nilai reliabilitas sebesar 0,96 yang menunjukkan reliabilitas item termasuk kategori bagus sekali. 
Butir soal yang dikatakan valid adalah butir soal yang memenuhi kriteria outfit MNSQ, outfit ZSTD dan PT measure correlation. Adapun rentang yang diperbolehkan untuk outfit MNSQ yaitu 0,5 sampai dengan 1,5 , outfit ZSTD yaitu -2,0 sampai dengan 2.0, dan PT measure correlation yaitu 0,4 sampai dengan 0,85 $5^{[19]}$. Butir dapat dikatakan valid atau dapat diterima apabila memenuhi minimal 2 dari 3 kriteria, apabila butir soal hanya memenuhi 1 dari 3 kriteria saja maka butir tersebut tidak dapat digunakan $^{[22]}$. Berdasarkan Tabel 9, dari 13 butir soal terdapat 4 butir soal yang hanya memenuhi 2 dari kriteria, yaitu soal nomor 1.3, 3.1, 5.1, dan 5.2. Butir soal 1.3, 3.1, 5.1, dan 5.2 ini tergolong kategori valid dan dapat digunakan. Sementara 9 butir soal lainnya memenuhi semua kriteria yang menunjukkan bahwa soal tersebut valid.

\section{SIMPULAN}

Berdasarkan penelitian yang telah dilakukan, instrumen literasi kimia pada materi ikatan kimia memiliki kategori valid dari segi konten yang memperoleh hasil persetujuan penguji (exact agreements) sebesar $86,8 \%$ dan hasil perkiraan persetujuan (expected agreements) sebesar 87,8\%. Hal ini menunjukkan bahwa hasil penilaian dari penguji tidak terlalu jauh berbeda dengan hasil penilaian yang diharapkan. Sedangkan berdasarkan pengujian validitas butir soal menunjukkan semua butir soal dikatakan valid dan dapat digunakan. Sementara nilai reliabilitas item yang diperoleh adalah 0,96 yang menunjukkan reliabilitas item termasuk kategori baik sekali.

\section{REFERENSI}

1. Perdana NS. Analysis of Student Readiness in Facing Minimum Competency Assesment. Jurnal Pendidikan, Sejarah, dan Ilmu-ilmu Sosial. 2021;5(1):15-20,

2. Yuliandari RN, Hadi S. Implikasi Asesmen Kompetensi Minimum Dan Survei Karakter Terhadap Pengelolaan Pembelajaran SD. Ibriez Jurnal Kependidikan Dasar Islam Berbas Sains. 2020;5(2):203-219.

3. Thummathong R, Thathong K. Chemical literacy levels of engineering students in Northeastern Thailand. Kasetsart Journal of Social Sciences. 2018;39(3):478-87.

4. Wulandari N, Sholihin H. Analisis Kemampuan Literasi Sains Pada Aspek Pengetahuan Dan Kompetensi Sains Siswa SMP Pada Materi Kalor. Edusains 2016;8(1):66-73.

5. Narut YF, Supradi K. Literasi Sains Peserta Didik Dalam Pembelajaran Ipa di Indonesia. Jurnal Inovasi Pendidikan Dasar. 2019;3(1):61-69.

6. Fahmina SS, Indriyanti NY, Setyowati WAE, Masykuri M, Yamtinah S. Dimension of Chemical Literacy and its Influence in Chemistry Learning. Journal of Physics Conf. Ser. 2019;1233(1).

7. Raharjo MWC, Suryati, Khery Y. Pengembangan
E-Modul Interaktif Menggunakan Adobe Flash Pada Materi Ikatan Kimia Untuk Mendorong Literasi Sains Siswa. Jurnal Ilmiah Pendidikan Kimia Hydrogen. 2017;5(1).

8. Arabbani FK, Mulyani S, Mahardiani L, Ariani SRD. Analysis The Quality of Instrument For Measuring Chemical Literacy Abilities Of High School Student Using Rasch Model. AIP Conference Proceedings. 2019;2194(1).

9. Sadhu S, Laksono EW. Development and Validation of an Integrated Assessment for Measuring Critical Thinking and Chemical Literacy in Chemical Equilibrium. International Journal of Instruction. 2018;11(3):557-572.

10. Fahmina SS, Masykuri M, Ramadhani DG, Yamtinah S. Content Validity Uses Rasch Model on Computerized Testlet Instrument to Measure Chemical Literacy Capabilities. AIP Conference Proceedings. 2019;2194(1).

11. Yusmaita E, Anthonio LG, Rivaldo I. Chemical Literacy Test Instrument Designing on Buffer Topic using Model of Educational Reconstruction (MER). Journal of Physics: Conference Series. 2021;1788(2021).

12. Thummathong R, Thathong K. Construction of A Chemical Literacy Test for Engineering Students. Journal of Turkish Science Education. 2016;13(3):185-198.

13. Afifah S, Yusmaita E. Perancangan Assesmen Literasi Kimia Pada Materi Termokimia Kelas XI SMA/MA. Edukimia 2019;1(4):79-83.

14. Yusmaita E, Nasra E. Perancangan Assesmen Literasi Kimia Dengan Menggunakan Model of Educational Rekonstruction (Mer) Pada Tema: “Air Sebagai Pelarut Universal.” Jurnal Eksakta Pendidikan (JEP) 2017;1(2):49-55.

15. Sumarni W, Sudarmin, Wiyanto, Supartono. Preliminary Analysis of Assessment Instrument Design to Reveal Science Generic Skill and Chemistry Literacy. International Journal of Evaluation and Research in Education (IJERE). 2016;5(4):331-340,

16. Rusilowati A, Kurniawati L, Nugroho SE, Widiyatmoko A. Developing an Instrument of Scientific Literacy Asessment on The Cycle Theme. International Journal of Environmental and Science Education. 2016;11(12):5718-5727.

17. Shwartz Y, Ben-Zvi R, Hofstein A. The Use of Scientific Literacy Taxonomy for Assessing The Development of Chemical Literacy Among High-School Students. Chemistry Education Research and Practice. 2006;7(4):203-225.

18. Retnawati H. Analisis Kuantitatif Instrumen Penelitian. Yogyakarta: Parama Publishing; 2016.

19. Sumintono B, Widhiarso W. Aplikasi Model Rasch Untuk Penelitian Ilmu-Ilmu Sosial. Cimahi: Trim Komunikata Publishing House; 2013.

20. Rusilowati A. Asesmen Literasi Sains: Analisis Karakteristik Instrumen dan Kemampuan Siswa Menggunakan Teori Tes Modern Rasch 
Model. Prosiding Seminar Nasional Fisika

Universitas Riau ke-3 2018;(September):2-15.

21. Duit R, Gropengießer H, Kattmann U, Komorek M, Parchmann I. The Model of Educational Reconstruction - A Framework For Improving Teaching and Learning Science. Science Education Research and Practice in Europe Retrosspective and Prospecctive 2012;13-37.

22. Palimbong J, Mujasam, Allo AYT. Item Analysis Using Rasch Model in Semester Final Exam Evaluation Study Subject in Physics Class X TKJ SMK Negeri 2 Manokwari. Kasuari: Physics Education Journal (KPEJ). 2018;1(1):43-51. 